\title{
MANAJEMEN SUMBER DAYA MANUSIA DALAM MENINGKATKAN MUTU PENDIDIKAN
} DI SMK PELITA GEDONG TATAAN

\author{
Rih Ayuningsih, Muhtarom, Syeh Al Ngarifin \\ J1. Raya Wonokriyo Gadingrejo Pringsewu \\ Email: stitpringsewu@gmail.com
}

\begin{abstract}
This study aims to determine the implementation of Human Resource Management in SMK Pelita Gedong Tataan District Pesawaran. To know the successful implementation of Human Resource Management related to the development of teacher professionalism and discipline in order to improve the quality of education in SMK Pelita Gedong Tataan. This research is a qualitative field research with data collection techniques that are: observation, interview, and documentation. Data analysis in this research is descriptive analysis technique.

In implementing Human Resource Management, steps taken by SMK Pelita Gedong Tataan begins with planning everything that will be done in improving the quality of education, such as with the recruitment and selection of educators and education, then planning is organized according to the needs of the school. The next step is the implementation of a predetermined plan and guidance then supervision and evaluation is the final step in implementing Human Resource Management related to teacher professional development and discipline in order to improve the quality of education.

Implementation of Human Resource Management in an effort to improve the quality of education in SMK Pelita Gedong Tataan Gedong Tataan District Pesawaran Regency has been quite successful in improving the quality of education. This is indicated by the passing rate of students who reach one hundred percent.
\end{abstract}

\begin{abstract}
Abstrak
Penelitian ini bertujuan untuk mengetahui implementasi MSDM di SMK Pelita Gedong Tataan Kebupaten Pesawaran. Untuk mengetahui keberhasilan penerapan MSDM terkait pengembangan profesionalisme guru dan kedisiplinan dalam rangka meningkatkan mutu pendidikan di SMK Pelita Gedong Tataan. Penelitian ini merupakan penelitian kualitatif lapangan dengan teknik pengumpulan data yaitu: observasi, wawancara, dan dokumentasi. Analisis data dalam penelitian ini berupa teknik analisis deskriptif.

Dalam mengimplementasikan Manajemen Sumber Daya Manusia, langkah langkah yang dilakukan SMK Pelita Gedong Tataan diawali dengan merencanakan segala sesuatu yang akan dilakukan dalam meningkatkan mutu pendidikan, seperti dengan adanya rekrutmen dan seleksi terhadap tenaga pendidik dan kependidikan, kemudian perencanaan tersebut diorganisir sesuai kebutuhan sekolah. Langkah langkah selanjutnya adalah pelaksanaan dari rencana yang telah ditetapkan dan pengarahan kemudian pengawasan serta evaluasi merupakan langkah akhir dalam mengimplementasikan Manajemen Sumber Daya Manusia terkait pengembangan profesioanalisme guru dan kedisiplinan dalam rangka meningkatkan mutu pendidikan. Implementasi Manajemen Sumber Daya Manusia dalam upaya meningkatkan mutu pendidikan di SMK Pelita Gedong Tataan Kecamatan Gedong Tataan Kabupaten Pesawaran telah cukup berhasil meningkatkan mutu pendidikan. Hal ini terindikasi dari tingkat kelulusan siswa yang mencapai seratus persen.
\end{abstract}

Kata Kunci: Manajemen, Sumber Daya Manusia, Mutu 


\section{A. PENDAHULUAN}

Sekolah merupakan lembaga penentu dalam kiprah pengembangan pendidikan, karena dari deretan birokrasi yang terkait dengan pengembangan pendidikan, sekolah sebagai pelaksana dari semua program pendidikan yang direncanakan dari tingkat pusat sampai ke tingkat operasional di sekolah. Maju mundurnya pendidikan sangat ditentukan oleh pelaksanaan yang ada di tangan para pendidik di sekolah (Abubakar \& Nurjan, 2009: 1-10).

Menurut Uno (2007:22), Kunci utama agar perencanaan dan program-program pengembangan pendidikan di sekolah berjalan optimal berada di tangan para pendidik dan tenaga kependidikan di sekolah. Dengan demikian jelaslah masalah peningkatan profesionalisme ketenagaan sangatlah penting untuk diperhatikan.

Di penghujung abad ke dua puluh dan memasuki melenium ketiga yang ditandai dengan eraglobalisasi, semua bangsa berusaha untuk meningkatkan sumber daya manusia. Termasuk sumber daya pendidikan (Shertian, 2008:2). Keberhasilan organisasi (Fathoni, 2009:1) dalam mencapai tujuan dan sasarannya serta kemampuannya menghadapi berbagai tantangan, baik yang sifatnya eksternal maupun internal, sangat ditentukan oleh kemampuan mengelola sumberdaya manusia kemajuan ilmu pengetahuan dan teknologi di Negara maju maupun dinegara berkembang ditentukan oleh perkembangan manajemen sumber segala bidang.

Manajemen sumber daya manusia (Fathoni, 2009:8), terdiri dari empat suku kata yaitu manajemen, sumber, daya dan manusia, keempat suku kata terbukti tidak sulit untuk dipahami artinya. Yang dimaksud dengan sumber daya manusia adalah proses pengendalian berdasarkan fungsi manjemen terhadap daya yang bersumber dari manusia.

Manajemen Sumber Daya Manusia merupakan bagian dari ilmu manajemen yang memfokskan perhatiaanya pada pengaturan peranan sumber daya manusia dalam kegiatan organisasi. Beberapa pakar MSDM menberikan pandangan yang beragam tentang MSDM. Seperti yang dikemukakan Milkovich and Boudreau (1997:2), MSDM itu merupakan integrasi keputusan yang berbentuk hubungan antar karyawan, kualitas sinergi mereka memberikan kontribusi terhadap kemempuan SDM dan organisasi dalam mencapai tujuan. Sedangkan Hasibuan (2013:10) menyatakan bahwa manajemen sumber daya manusia merupakan ilmu atau seni mengatur hubungan dan peranan tenaga kerja agar efektif dan efesien membantu terwujudnya tujuan perusahaan, karyawan dan masyarakat.

Secara ringkas pernyataan pakar diatas pada dasarnya menyatakan MSDM itu merupakan penggunaan SDM untuk mencapai tujuan organisasi seperti dikemukakan oleh Mondi Noe and Premeaux (1999:4), mengemukakan bahwa manajemen sumber daya manusia adalah pemanfaatan sumber daya manusia untuk mencapai tujuan organisasi. Organisasi yang di maksud dalam tulisan ini disamakan dengan lembaga pendidikan atau sekolah.

Berkenaan dengan pentingnya MSDM dalam rangka meningkatkan mutu pendidikan dekemukan oleh Uhar Suharsaputra (http//uharsaputra.Wordpress.com) sebagai berikut:

"Manajemen sumber daya manusia merupakan faktor yang akan menentukan pada kinerja organisasi, ketepatan pemanfaatan dan pengembangan sumber daya manusia serta mengintegrasikannya dalam satu kesatuan gerak dan arah organisasi akan menjadi hal penting dalam peningkatan kapasitas organisasi dalam mencapai tujuannya".

Fungsi manajemen sumber daya manusia pada dasarnya meliputi perencanaan, pengorganisasian, pengarahan, pengendalian, pengadaan, pengembangan, kompensasi, pengitegrasian, pemeliharaan, kedisiplinan dan pemberhentian( Hasibuan, 2013:21). Dalam proses perencanaan, langkah- langkah dalam perencanaan SDM dimulai dengan mempertimbangkan tujuan dan strategi oprasional. Kemudian harus dilakukan penilaian baik eksternal maupun internal akan kebutuhan dan sumber pasokan SDM dan mengembangkan peramalan (Robert dan Jackson, 2011:75). Selanjutnya dalam proses pelaksanaan (Husaini, Usman,2013:534) perlu adanya proses pemantauan, penilaian dan pelaporan rencana atas tujuan yang telah ditetapkan untuk tindakan korektif guna penyempurnaan lebih lanjut. Selain itu juga perlu usaha untuk meningkatkan kemampuan teknis, teoritis, konseptual, dan moral karyawan/tenaga kerja sesuai dengan kebutuhan pekerjaan/jabatan melalui pendidikan dan latihan (Hasibuan, 2013:68). Hal ini sangat penting untuk meningkatkan mutu atau kualitas pendidikan yang berdampak pada peserta didik itu sendiri.

Menurut Crosby mutu ialah sesuai dengan yang disyaratkan atau distandarkan. Kemudian Hadis \& Nurhayati (2012:85), menyatakan bahwa mutu ialah Suatu produk memiliki mutu apabila sesuai dengan standar atau kriteria mutu yang telah ditentukan, standar mutu tersebut meliputi bahan baku, proses produksi dan produk jadi.

Tidak dapat dipungkiri bahwa mutu pendidikan di Indonesia masih jauh yang diharapkan, apalagi jika dibandingkan dengan mutu pendidikan di negara lain. Hasil survey Political and Economoc Risk Consultancy (PERC) yang dilakukan pada tahun 2000 tentang mutu pendidikan dikawasan Asia, menempatkan Indonesia di rangking 12 
setingkat di bawah Vietnam (Hadis \& Nurhayati , 2012:1). Rendahnya sumber daya manusia Indonesia berdasarkan hasil survey UNDP tersebut adalah akibat rendahnya mutu pendidikan diberbagai jenis dan jenjang pendidikan, karena itu salah satu kebijakan pokok pembangunan pendidikan nasional ialah meningkatkan mutu dan relevansi pendidikan. Selain itu, perluasan dan pemertaan pendidikan serta akuntabilitas juga menjadi kebijakan pembangunan pendidikan Nasional (UU Setandar Pendidikan Nasional Nomor 20 Tahun 2005).

Mengingat esensinya masalah mutu, ditegaskan oleh Syafaruddin (2005:34) bahwa Konsep sekolah bermutu ( unggul ) perlu ada dalam konsep setiap Kepala sekolah. Oleh karena itu perlu adanya manjemen yang secara khusus menangani masalah yang melibatkan manajemen sumber daya pendidikan yakni guru, salah satunya dengan cara pengimplememtasian manajemen sumber daya guru dalam dalam upaya meningkatkan mutu pendidikan seperti dengan adanya pengembangan profesionalisme guru karena guru profesional sebagai faktor penentu mutu pendidikan. guru wajib mengembangkan kemampuan profesionalnya agar dapat meningkatkan kinerja dalam melaksanakan tugas, karena pendidikan dimasa yang akan datang menuntut keterampilan profesi pendidikan yang bermutu (Megarry dan Dean, 1999:1214).

Kemudian upaya peningkatan profesi guru Indonesia sekurang kurangnya menghadapi dan memperhitungkan empat faktor, yaitu: (1) ketersediaan dan mutu calon guru, (2) pendidikan pra jabatan, (3) mekanisme pembinaan dalam jabatan dan (4) peranan organisasi profesi (Basyiruddin dan Syarifuddin, 2003:24).

Peningkatan kinerja juga penting dilakukan oleh guru itu sendiri atau atas pengaruh motivasi kepala sekolah. Namun kondisi kerja para guru baik yang sifatnya fisik maupun non fisik masih belum memberikan derajat kepuasan kerja sehingga mempengaruhi kinerja guru. Kondisi kerja berupa kelas bocor, lantai pecah, kekurangan alat bantu dan iklim hubungan guru yang kurang baik mempengaruhi kinerja dan kepuasan kerja guru.

Berdasarkan uraian diatas dapat penulis simpulkan bahwa manajemen sumber daya manusia khususnya dalam lembaga pendidikan merupakan unsur yang sangat diperlukan untuk mengembangkan sekaligus meningkatkan mutu pendidikan demi terealisasikannya tujuan pendidikan, hal ini disebabkan karena salah satu unsur pencapaian mutu pendidikan ditentukan oleh sumber daya manusia, singkatnya manajemen sumber daya manusia memiliki peranan yang sangat urgen dalam peningkatkan mutu pendidikan hal ini dapat dirasakan oleh lembaga- lembaga pendidikan khususnya di
SMK Pelita Gedong Tataan. Atas dasar tersebut penulis tertarik untuk mengadakan penelitian dengan judul "Implementasi Manajemen Sumber Daya Manusia Dalam Meningkatkan Mutu Pendidikan di SMK Pelita Gedong Tataan Kecamatan Gedong Tataan Kabupaten Pesawaran".

\section{B. TUJUAN}

Tujuan yang hendak dicapai dalam penelitian ini adalah sebagai berikut:

1. Untuk mengetahui implementasi MSDM di SMK Pelita Gedong TataanKebupaten Pesawaran.

2. Untuk mengetahui keberhasilan penerapan MSDM terkait pengembangan profesionalisme guru dan kedisiplinan dalam rangka meningkatkan mutu pendidikan di SMK Pelita Gedong Tataan.

\section{METODE PENELITIAN}

Metode yang penulis gunakan dalam penelitian ini adalah metode "deskriftif survey" dimana penelitian ini dimaksudkan untuk mengukurdengan cermat sejauh mana penerapan Menejemen Sumber Daya Manusia yang dilakukan di SMK Pelita Gedong Tataan Kecamatan Gedong Tataan Kabupaten Pesawaran.

Adapun Jenis penelitian yang penulis gunakan adalah jenis penelitian fielf research, yaitu jenis penelitian yang secara langsung meneliti fakta lapanga, sementata sifat penelitian ini adalah deskriptif, dimana dalam penelitian ini penulis menggambarkan kondisi lapangan apa adanya.

Dalam melakukan penelitian ini data data yang diperlukan diperoleh dari dua sumber yaitu :

\section{Data Primer}

Data yang diperoleh dari sumbernya secara langsung, diamati dan dicatat secara langsung, seperti, wawancara dan dokumentasi.

Data primer adalah data yang bersumber dari informan yang mengetahui secara jelas dan rinci mengenai masalah yang sedang diteliti. Adapun yang menjadi sumber data primer dalam penelitian ini data yang berkaitan dengan Sumber Daya Manusia ( guru tenaga pendidik dan kependidikan ) SMK Pelita Gedong Tataan. 2. Data Sekunder

Data sekunder adalah data yang diperoleh data yang sudah ada dan mempunyai hubungan masalah yang diteliti yaitu meliputi literaturliteratur yang ada.Selain itu data ini juga dapat diperoleh dari data-data dokumentasi berupa profil SMK Pelita Gedong Tataan, keadaan guru, keadaan siswa, sarana dan prasarana yang dimiliki. 
Tabel 1

Populasi Penelitian

\begin{tabular}{|c|c|c|}
\hline No & Populasi & Jumlah \\
\hline 1 & Kepala Sekolah & 1 orang \\
\hline 2 & Guru & 35 orang \\
\hline 3 & Pegawai/Staf & 7 orang \\
\hline & Jumlah & 42 orang \\
\hline
\end{tabular}

Sumber: Data Guru dan Pegawai/Staf SMK

Pelita Gedong Tataan 15Agustus 2015

Prosedur Pengumpulan Data/ Alat Pencari Datanya adalah wawancara, observasi dan dokumentasi. Selanjutnya dalam menganalisis data, penulis menggunakan analisa induktif yaitu cara penganalisaan data yang bertitik tolak dari hal hal khusus kemudian disimpulkan secara umum. Analisa induktif ini digunakan untuk menganalisa data yang diperoleh dari lapangan penelitian.

\section{PEMBAHASAN}

\section{Gambaran Umum Objek Penelitian}

Guru atau pendidik dalam dunia pendidikan mempunyai peranan yang sangat penting sehingga seringkali dijadikan tolak ukur berhasil tidaknya pendidikan di suatu sekolah. Sampai berakhirnya masa penelitian ini guru yang tertulis sebagai pengajar di SMK Pelita sebanyak 53 orang. Yang terdiri dari 1 guru tetap (PNS) dan 52 guru honorer. Masingmasing guru memiliki latar belakang pendidikan yang berbeda-beda. Sedangkan tenaga kependidikan yang lain (karyawan) punya peranan penting untuk menopang tercapainya tujuan tersebut. Jumlah karyawan atau staff tata usaha (TU) sebanyak 7 orang, dengan jumlah karyawan laki-laki 5 orang dan karyawan perempuan 2 orang.

Berdasarkan data yang didapatkan ternyata terdapat sebagian kecil guru yang mengajarkan tidak sesuai dengan latar belakang pendidikannya atau tidak sesuai dengan jurusannya seperti yang seharusnya guru B. Indonesia tetapi mengajarkan Pkn. Kenyataan ini seharusnya tidak terjadi, agar materi yang disampaikan seorang guru itu tidak tumpah tindih dengan kemampuan akademik yang dimilikinya sehingga guru kurang menguasai materi yang akan diajarkan.
Tabel 3

Data Tenaga Administrasi SMK Pelita Gedong Tataan tahun pelajaran 2014/2015

\begin{tabular}{|c|c|c|c|}
\hline Nama & $\begin{array}{l}\mathrm{L} / \\
\mathrm{P}\end{array}$ & $\begin{array}{c}\text { Pendidikan } \\
\text { Terakhir }\end{array}$ & Jabatan \\
\hline Rubiyati & $\mathrm{P}$ & MA & Ka. Tata Usaha \\
\hline Apridayanti, A.Md. & $\mathrm{P}$ & D1 & Administrasi \\
\hline Thohir Zain & $\mathrm{L}$ & SMA & Tata Usaha \\
\hline Suratman & $\mathrm{L}$ & SMEA & Tata Usaha \\
\hline Komari & $\mathrm{L}$ & SMK & Tata Usaha \\
\hline Mat Saleh & $\mathrm{L}$ & SMA & $\begin{array}{c}\text { Petugas } \\
\text { Keamanan }\end{array}$ \\
\hline Sudarto & & SD & $\begin{array}{l}\text { Penjaga } \\
\text { Sekolah }\end{array}$ \\
\hline
\end{tabular}

(Sumber: Buku Program Kerja SMK Pelita, 2010)

Dari tabel di atas dapat dilihat bahwa karyawan tata usaha dan administrasi pada tahun ajaran 2013/2015 masih kurang memadai yaitu hanya 5 orang karyawan saja yang bertugas melayani 286 siswa. Hal ini menyebabkan sangat merepotkan karyawan tata usaha, tetapi walaupun begitu, karyawan tata usaha tetap berusaha memberikan pelayanan kepada siswa dan guru dengan sebaik-baiknya. Dan untuk satpam dan karyawan kebersihan sudah kurang memadai jumlahnyayaitu 1 orang satpam dan 1 penjaga sekolah.

Kemudian jumlah siswa pada tahun 2015/2016 yaitu sebanyak 286 orang. Untuk perinciannya dapat dilihat dalam tabel berikut ini:

Tabel 4

Data Siswa SMK Pelita Gedong Tataan Pelajaran 2015/2016

\begin{tabular}{|c|c|c|c|c|}
\hline \multirow{2}{*}{ Tahun } & \multicolumn{3}{|c|}{ Kelas } & \multirow{2}{*}{ Jumlah } \\
\cline { 2 - 4 } & $\mathbf{X}$ & $\mathbf{X I}$ & XII & \\
\hline $2010 / 2011$ & 322 & 275 & 300 & 897 \\
\hline $2011 / 2012$ & 307 & 285 & 252 & 844 \\
\hline $2012 / 2013$ & 276 & 288 & 275 & 839 \\
\hline $2013 / 2014$ & 290 & 265 & 281 & 836 \\
\hline $2014 / 2015$ & 328 & 273 & 259 & 860 \\
\hline $2015 / 2016$ & 286 & 328 & 273 & 887 \\
\hline Jumlah & 1809 & 1714 & 1640 & 5163 \\
\hline
\end{tabular}

(Sumber: Buku Program Kerja Pelita, 2010)

Dari tabel di atas dapat dilihat bahwa data jumlah siswa SMK Pelita dari tahun 2010/2013 semakin berkurang tetapi pada tahun 2014/2015 jumlah siswa meningkat. Kenyataan ini karena SMK Pelita belum mempunyai sarana dan prasarana yang memadai sehingga belum menunjukan cukup prestasi. Namun, seiring waktu berjalan sedikit demi sedikit SMK Pelita mulai menunjukan peningkatan dalam prestasi. Hal ini dikarnakan SMK Pelita mulai memperhatikan dan melengkapi sarana dan prasarana yang dibutuhkan siswa untuk kegiatan ekstrakulikuler, dengan begitu SMK Pelita 
menjuarai beberapa perlombaan hal ini menarik minat anak untuk bersekolah di SMK Pelita.

\section{Implementasi Manajemen Sumber Daya Manusia}

Berdasarkan hasi interview dangan Kepala Sekolah terkait pengembangan Profesionalisme Guru dan kedisiplinan dalam rangka meningkatkan mutu penndidikan di SMK Pelita Gedong Tataan beliau menyatakan:

Upaya yang dilakukan dalam pengembangan profesionalisme Guru adalah dengan mengadakan pembinaan pembinaan personel tenaga pendidik dan kependidikan baik dalam bentuk pelatihan yang yang diselenggarakan oleh kementrian agama maupun mandiri yang dilakukan di sekolah seperti pembinaan MGMP, pelatihan personel tenaga kepustakaan melalui undangan, bimtek dan sosialisasi kurikulum 2013.

Selaras dengan peryataan diatas Waka Kurikulum menyatakan:

Upaya yang dilakukan dalam pengembangan Profesionalisme Guru dan pegawai adalah dengan melalui pembinaan, pelatihan baik yang dilkukan oleh lembaga pendidikan maupun dari pihan Kementrian Agama, seperti pelatihan dalam pembuatan Rencana Pelaksanaan Pembelajaran ( RPP ) Pengembengan Kurikulum, evaluasi pembelajaran dan lain sebagainya.

Hasil wawancara tersebut menunjukan bahwa implementasi yang dilakukan Kepala Sekolah terkait pengembangan profesionalisme Guru dalam rangka meningkatkan mutu pendidikan cukup baik, dimana Kepala sekolah mengadakan sejenis pelatihan dan pembinaan terhadap dewan guru dan pegawai serta dengan mengutus para guru untuk mengikuti pelatihan diluar sekolah seperti dengan mengikuti MGMP, Sosialisasi Kurikulum dan lain sebagainya. Kemudian untuk lebih jelasnya dapat dilihat pada pembahasan dibawah ini.

\section{a. Perencanaan}

Perencanaan yang dilakukan Kepala Sekolah SMK Pelita Gedong Tataan dalm mengimplementasikan Manajemen Sumber Daya Manusia terkait pengembangan profesionalisme guru dan kedisiplinan dalam rangka meningkatkan mutu pendidikan, Kepala Sekolah menyatakan:

Tahap yang paling dasar dalam proses ini adalah analisis terhadap kebutuhan sekolah, seleksi tenaga pendidik dan kependidikan. Denganya dapat diketahui bahwa kebutuhan apa saja yang dibutuhkan dalam pelaksanaan perencanaan MSDM. Jika terdapat personel tenaga pendidik dan kependidikan yang kurang menguasai maka dilakukan pembinaan.

Berdasarkan hasil wawancara tersebut diatas terkait dengan perencanaan MSDM pengembangan profesionalisme guru dan kedisiplinan dapat diperoleh hasil bahwa upaya yang dilakukan Kepala Sekolah dalam proses perencanaan adalah dengan menganalisis kebutuhan sekolah, mengidentifikasi jumlah tenaga pendidik, seleksi tenaga pendidik dan kependidikan agar sesuai dengan kebutuhan sekolah.

Selaras dengan pernyataan para dewan guru, dimana para guru menilai bahwa Kepala sekolah cukup aktif dalam hal perencanaan MSDM terkait pengembangan profesionalisme guru dan kedisiplinan dalam menganalisis kebutuhan sekolah terlebih dahulu kemudian menyeleksi SDM agar dapat sesuai dengan kebutuhan sekolah dan efektif dalam pelaksanaan proses MSDM sesuai dengan perencanaan yang telah ditetapkan sehingga dapat mudah untuk mencapai tujuan yang diharapkan yakni peningkatan tarhadap mutu pendidikan.

b. Pengorganisasian

Bentuk pengorganisasian Sumber Daya Manusia terkait pengembangan profesionalisme guru dan kedisiplinan dalam mengajar berdasarkan latar pendidikanya yakni, guru yang memiliki latar pendidikan agama seperti fikih, Al-Quran Hadits, Aqidah Akhlak, Sejarah Kebudayaan Islam, Bahasa Arab serta muatan local Bimbingan Praktik Ibadah. Kemudian guru yang memiliki latar belakang pendidikan Bahasa Indonesia, Bahasa Inggris dan Matematikapun mengempu pelajaran yang sesuai dengan latar belakang pendidikanya serta mata pelajaran Pendidikan Jasmani juga diampu oleh guru yang memiliki latar belakang sekolah tinggi olah raga. Dengan demikian bentuk pengorganisasian yang dilakukan oleh Kepala sekolah SMK Pelita Gedong Tataan dinilai sudah cukup baik dalam mengimplementasikan MSDM dalam meningkatkan mutu pendidikan di SMK Pelita Gedong Tataan.

c. Pengarahan

Bentuk pengarahan yang dilakukan oleh Kepala sekolah dalam mengimplementasikan MSDM dalam rangka meningkatkan mutu pendidikan di SMK Pelita Kepala SMK Pelita menyatakan:

Bentuk pengarahan yang dilakukan adalah dengan mengadakan pembinaan profesionalisme, pembinaan kesejahteraan guru, pengaturan pemindahan dan pemberhentian guru dan pegawai serta memberikan motivasi terhadap kinerja guru dan pegawai.

Berdasarkan ungkapan Kepala sekolah diatas, dapat diperoleh hasil bahwa pengarahan yang dilakukan Kepala sekolah dalam mengimplementasikan MSDM dalam rangka meningkatkan mutu pendidikan di SMK Pelita dinilai sudah cukup baik, hal ini dapat dilihat dari upaya yang dilakukan Kepala sekolah, mulai dari memberikan pembinaan profesionalisme guru dan pegawai serta mengirim guru untuk mengikuti MGMP, Seminar dan Workshop yang berkaitan dengan 
pengembangan profesionalisme guru, pembinaan terhadap pengembangan kurikulum serta memberikan peluang kepada para guru dan pegawai untuk melanjutkan pendidikan kejenjang yang lebih tinggi. Kemudian pembinaan terhadap kesejahteraan guru dan pegawai, seperti dengan memberikan gaji rutin disetiap bulan dan memberikan tunjangan penghargaan terhadap guru yang mendapatkan prestasi dalam kinerjanya.Kemudian pemberian motivasi terhadap kinerja guru dan pegawai serta mencipatkan iklim yang kondusif.

\section{d. Pengawasan}

Pengawasan atau evaluasi yang dilakukan Kepala sekolah untuk mengiplementasikan MSDM terkait pegembangan Profesionalisme guru, Kepala sekolah menyatakan:

Evaluasi yang dilakukan adalah dengan cara pemantauan kinerja guru dan pegawai, pengawasan melekat dan penilaian terhadap kinerja guru dan pegawai. Jika terdapat kesalahan maka dilakukan pemberitahuan dan teguran terhadap kinerja personel tenaga pendidik dan kependidikan.

Berdasarkan hasil interview diatas dapat diperoleh hasil bahwa bentuk pengawasan yang dilakukan Kepala sekolah untuk mengimplementasikan MSDM dinilai sudah cukup baik, hal ini dapat dilihat dari upaya yang dilakukan kepala sekolah dalam mengevaluasi MSDM.Upaya yang dilakukan kepala sekolah adalah mulai dari melakukan pemantauan terhadap kinerja guru, pengawasan melekat dan penilaian terhadap kinerja guru.Selain itu dengan melakukan penilaian terhadap prestasi kerja guru.

Berdasarkan Interview penulis dengan kepala Sekolah dapat diperoleh hasil bahwa Implementasi Menejemen Sumber Daya Manusia terkait pengembangan profesionalisme guru dan kedisiplinan dalam rangka meningkatkan mutu pendidikan di SMK Pelita Gedong Tataan telah dilakukan dengan cukup baik, dimana kepala sekolah berusaha untuk Manajemen Sumber Daya Manusia dengan baik, dengan melalui proses dan tahapan tahapan yang dilakukan yakni, dengan melalui proses perencanaan, pengorganisasiann dan pengawasan.

Pada tahap perencanaan telah dianalisis kebutuhan dan hal hal yang akan dilaksanakan serta siapa yang akan melaksanakan seperti adanya seleksi dalam pengadaan guru dan karyawan agar sesuai dengan kebutuhan sekolah, kemudian jika terdapat guru yang kurang kompeten baik dari segi kualitas maupun kuantitasnya, maka kepala sekolah akan berupaya untuk mengadakan pengembangan terhadap guru tersebut dengan melalui pembinaan, pelatihan maupun pendidikan yang sesuai dengan pootensi yang dimilikinya. Bentuk pengembangan yang dilakukan kepala SMK Pelita Gedong Tataan adalah dengan mengutus dewan guru dan pegawai untuk mengikuti pelatihan dan MGMP dan memberi kesempatan kepada guru dan pegawai untuk melanjutkan pendidikan kejenjang yang lebih tinggi sehingga dapat maksimal dalam meningkatkan mutu sekolah.

Kemudian hasil perencanaan diorganisir sesuai dengan ketentuan dan kebutuhan sekolah melalui penempatan pembagian kerja, menetapkan guru mata pelajaran sesuai dengan latar belakang pendidikan yang dimilikinya, memonitoring kinerja secara structural, memperjelas alur koordinasi kerja dengan membuat struktur sekolah dan mengadakan rapat koordinasi yang dilakukan pada awal tahun ajaran baru, pertengahan semester dan akhir tahun. Selain itu kepala sekolah juga memberikan pengarahan kepada dewan guru dan pegawai agar proses pembelajaran dapat berjalan dengan evektif, sehingga tujuan yang telah direncanakan dapat tercapai ( pendidikan yang bermutu ).

Setelah teroganisir secara baik, kemudian dilakukan pengerahan atau pelaksanaan program program yang telah direncanakan.Pelaksanaan dari tugas tugas tersebut tentu saja sesuai dengan yang telah ditetapkan dalam pengorganisasian.

Tahap akhir adalah pengawasan, pada tahap ini segala kegiatan yang dilaksanakan selalu diawasi untuk kemudian dievaluasi, dengan melalui pemantauan kinerja guru dan pegawai, pengawasan melekat, penilaian terhadap kinerja guru dan pegawai, penilaian prestasi kerja serta pemberian teguran atau pemberitahuan jiksa diantara guru dan pegawai terdapat kesalahan dalam kinerjanya dan hasilnya dapat digunakan sebagai umpan balik bagi perbaikan program program selanjutnya.

Kemudian selain dari usaha kepala sekolah untuk MSDM terkait dengan pengembangan professioanlisme guru dan kedisiplinan dalam rangka meningkatkan mutu pendidikan di SMK Pelita Gedung Tataan dewan guru dan pegawai pun ikut andil dalam penerapann MSDM tersebut.

Upaya kepala sekolah dalam mengimplementasikan MSDM terkait pengembangan profesionalisme guru dan kedisiplinan sudah cukup baik, seperti yang telah kami rasakan selama ini, misalnya dengan memberikan motivasi kepada dewan guru dalam proses pembelajaran. Kepala sekolah dinilai oleh para guru cukup baik dalam memotivasi, karena mampu menggerakan guru untuk berprestasi. Menurut Muhajir, kepala sekolah sudah cukup memberi motivasi kepada guru guru untuk meningkatkan prestasi dan kemampuanya, salah satunya dengan mendorong para guru untuk melanjutkan pendidikan kejenjang yang lebih tinggi.

Kemudian segenap dewan guru pun tidak hanya diam saja melihat upaya kepala sekolah 
tersebut, dewan guru juga ikut berupaya dalam pengembangan MSDM tersebut yakni, dengan melalui pemenuhan terhadap kewajiban sebagi guru dengan menyusun rencana pembelajaran sebelum KBM, mengembangkan kurikulum, disiplin dan konsisten terhadap kerja serta berupaya melakukan pengembangan terhadap potensi yang kami miliki, sehingga kami dapat memperoleh kepuasan dalam kerja dan hasilnya tujuan pendidikan pun dapat tercapai dengan kata lain pendidikan bermutu dapat dicapai.

Kemudian dalam rangka membantu mewujudkan upaya kepala sekolah dalam mengimplementasikan MSDM terkait pengembangan profesionalisme guru dan kedisiplinan dalam rangka mewujudkan pendidikan yang bermutu, kami selaku dewan guru ikut andil dalam hal tersebut melalui menyusun program pembelajaran, Rencana Pelaksaan Pembelajaran ( RPP ) sebelum pelaksanaan proses pembelajaran, mengembangkan kurikulum sesuai dengan lingkungan pendidikan di SMK Pelita, melaksanakan proses pembelajaran dengan evektif dan evaluasi terhadap hasil belajar serta berusaha untuk kerja keras dalam mencapai tujuan yang telah direncanakan yakni pendidikan yang bermutu.

Selain itu pegawai administrasi sekolahpun ikut andil dalam membantu upaya kepala sekolah untuk meningkatkan mutu pendidikan SMK Pelita dalam mengembangkan profesionalisme tenaga kependidikan melalui pengembangan ilmu teknologi dan komunikasi dengan cara mengikuti kursus computer agar dalam melaksanakan tugasnya di sekolah yakni dalam hal administrasi sekolah seperti penyusunan data data sekolah, data siswa dan guru serta promosi sekolah.

Berdasarkan beberapa pernyataan diatas dapat disimpulkan bahwa kepala sekolah SMK Pelita Gedong Tataan berusaha memanajemen SDM terkait pengembangan sumber daya guru dan kedisiplinan dengan baik dan dewan guru sebagai tenaga pendidik dan kependidikan ikut andil dengan berperan aktif dalam proses pembelajaran sehingga mutu pendidikan pun dapat dicapai.

Selain itu juga kepala SMK Pelita mengungkapkan bahwa setiap tahun dalam pelaksanaan UN siswanya lulus seratus persen. Hal ini menunjukan bahwa mutu siswa cukup baik.Dilihat dari status Sekolah sudah terakreditasi.Dengan demikian dapat dipahami mutu siswa dan sekolah sudah cukup baik.

Berdasarkan hasil pengamatan diperoleh hasil bahwa tampak beberapa aspek dalam implementasi MSDM terkait pengembangan profesionalisme guru dan kedisiplinan dalam rangka meningkatkan mutu pendidikan di SMK Pelita dikatakan cukup baik, sehingga dapat dikatakan bahwa implementasi Manajemen Sumber Daya Manusia di SMK Pelita Gedong
Tataan kecamatan Gedong Tataan Kabupaten Pesawaran telah dilaksanakan dengan cukup baik walaupun tidak seluruhnya dari beberapa aspek tersebut dikatakan belum cukup baik, oleh karena itu perlu adanya perbaikan terhadap pelaksanakan dari fungsi MSDM terkait pengembangan pprofesionalisme guru dan kedisiplinan agar kedepanya pelaksanaan MSDM dapat berjalan lancer sesuai dengan yang diharapkan.

Hal ini menunjukan bahwa implementasi Manajemen Sumber Daya Manusia dalam rangka meningkatkan mutu pendidikan di SMK Pelita Gedong Tataan sesuai dengan tahapan tahapan ynag telah ditentukan sehingga output yang dihasilkanpun baik dengan demikian mutu pendidikanpun sudah cukup baik, sehingga dapat dikatakan bahwa Implementasi MSDM dalam rangka meningkatkan mutu pendidikan di SMK Pelita Gedong Tataan telah dilaksanakan dengan cukup baik.

\section{E. PENUTUP}

\section{Kesimpulan}

Berdasarkan hasil penelitian dan pembahasan pembahasan sebelumnya, dapat disimpulkan bahwa :

1. Implementasi Manajemen Sumber Daya Manusia di SMK Pelita Gedong Tataan Kecamatan Gedong Tataan Kabupaten Pesawaran terkait Pengembangan Profesionalisme Guru dan Kedisiplinan dalam rangka meningkatkan mutu pendidikan sudah cukup baik, misalnya pada pada hari senin dewan guru harus sudah berada disekolah pada jam 07.00 WIB. Karena akan melaksanan upacara pengibaran bendera merah putih. Dengan mengimplementasikan Menejemen Sumber Daya Manusia kegiatan kegiatanya telah tersusun dan terorganisir dengan cukup baik.

2. Dalam mengimplementasikan Manajemen Sumber Daya Manusia, langkah langkah yang dilakukan SMK Pelita Gedong Tataan diawali dengan merencanakan segala sesuatu yang akan dilakukan dalam meningkatkan mutu pendidikan, seperti dengan adanya rekrutmen dan seleksi terhadap tenaga pendidik dan kependidikan, kemudian perencanaan tersebut diorganisir sesuai kebutuhan sekolah. Langkah langkah selanjutnya adalah pelaksanaan dari rencana yang telah ditetapkan dan pengarahan kemudian pengawasan serta evaluasi merupakan langkah akhir dalam mengimplementasikan Manajemen Sumber Daya Manusia terkait pengembangan profesioanalisme guru dan kedisiplinan dalam rangka meningkatkan mutu pendidikan.

3. Implementasi Manajemen Sumber Daya Manusia dalam upaya meningkatkan mutu pendidikan di SMK Pelita Gedong Tataan 
Kecamatan Gedong Tataan Kabupaten Pesawaran telah cukup berhasil meningkatkan mutu pendidikan. Hal ini terindikasi dari tingkat kelulusan siswa yang mencapai seratus persen.

2. Saran

1. Mengingat pentingnya MSDM dalam rangka meningkatkan mutu pendidikan di sekolah, maka kepala sekolah diharapkan dapat memahami masalah Manajemen Sumber Daya Manusia secara mendalam, baik melalui diklat kedinasan maupun belajar mandiri.

2. Dalam mengimplementasikan Manajemen Sumber Daya Manusia hendaknya kepala sekolah dapat melaksanakan dengan maksimal, agar efektif dan efisien kinerja sumber daya manusia yang ada semakin baik sehingga mutu pendidikanpun akan meningkat.

3. Hendaknya seluruh tenaga pendidik dan kependidikan dapat berperan aktif dalam melaksanakan tugas dan keajibanya demi meningkatkan mutu pendidikan yang diharapkan.

\section{Daftar Pustaka}

Abdul Hadis, Nurhayati, 2012, Manajemen Mutu Pendidikan,Bandung: Alfabeta.

Abdurrahman Fathoni, 2009, Organisasoi Dan Mnajemen Sumber Daya Manusia. Jakarta: Rineka Cipta.

Abu Bakar \& Nurjan. 2009. Profesi Keguruan. Surabaya:Aprinta.

Anisari, A., Purwanti, E., \& Masrur, M. (2017). Strategi Kepala Sekolah Dalam Meningkatkan Mutu Pembelajaran Di Smp Nurul Islam Kelurahan Garuntang Kecamatan Bumi Waras Kota Bandar Lampung. Jurnal Manajemen Pendidikan Islam Al-Idarah, 1(1), 1-9.

Dean, Megarry, 2007, Membangun Profesionalisme Guru, Bandung: Yrama Widya.

Husaini Usman. 2013. Manajemen Teori, Praktek, dan Riset Pendidikan (Edisi Empat), Bumi Aksara.

Kusuma, N., \& Purwanti, E. (2017). Pengaruh Kompetensi Pedagogik Dan Manajemen Pembelajaran Terhadap Penjaminan Mutu Pada Universitas Sang Bumi Ruwa Jurai Lampung. Indonesian Journal of Educational Counseling, 1(2), 209-226.

Malayu Hasibuan. 2013. Manajemen Sumber Daya Manusia Edisi Revisi. Jakarta:Bumi Aksara.

Milkivich and Boudreau. 1997. Manajemen Sumber Daya Manusia. Bandung: PT Citra Aditya.
Mondi Noe and Premeaux. 1999. Manajmen Pendidikan,. Jakarta: Gramedia.

Qoni'ah, N., Irawan, D., \& Purwanti, E. (2017). Penerapan Manajemen Sumber Daya Manusia (Msdm) Dalam Meningkatkan Kinerja Guru Di Smk Yasmida Ambarawa Kabupaten Pringsewu. Jurnal Manajemen Pendidikan Islam Al-Idarah, 2(2), 46-53.

Robert dan Jackson. 2011. manajemenn Umum. Jakarta: Bumi Aksara.

Shertian. 2008. Konsep Dsar \& Teknik Supervisi Pendidikan Dalam Rangangka pengembangan Sumber Daya Manusia. Jakarta:Rineka Cipta.

Syarifuddin, Nurdin, Basyiruddin Usman. 2003. Guru Provesional \& Implementasi Kurikulum, Jakarta: Ciputat Press.

Uno Hamzah B.. 2007. Profesi Kependidikan. Jakarta : Bumi Aksara.

UU Setandar Pendidikan Nasional Nomor 20 Tahun 2005. Tentang Pembangunan Pendidikan Nasional.

Uhar Saputra Tersedia : http//uharsaputra.Wordpress.com) diunduh tanggal 15 Agustus 2015 